\title{
The Empire that was always Decaying: The Carolingians (800-888)
}

\author{
Mayke de Jong*
}

This paper examines the potency of the concept of sempire in Carolingian history, arguing against the still recent trend in medieval studies of seeing the Carolingian empire as having been in a constant state of decay. An initial historiographical overview of medievalist's perceptions of sempire over the past century is followed by a discussion of how Carolingian authors themselves constructed, perceived and were influenced by notions of sempirer. Biblical scholars like Hraban Maur initiated an authoritative discourse on imperium, which in turn, after the 840s, heavily influenced later authors, perhaps most interestingly Paschasius Radbertus in his Epitaphium Arsenii. While the writings of these authors who looked back at Louis's reign have often been interpreted as revealing a decline of imperial ideals, they must rather be seen as testifying to a long-lasting concern for a universal Carolingian empire.

Keywords: Carolingian empire; Historiography; imperium; Louis the Pious; Staatlichkeit.

According to most textbooks, the first Western empire to succeed its late Roman predecessor suddenly burst upon the scene, on Christmas Day 800 in Rome, when Pope Leo III turned Charles, King of the Franks and Lombards, and patricius (protector) of the Romans, into an imperator augustus. Few events have been debated so much ad nauseam by modern historians as this so-called imperial coronation of 800 , which was probably not at all a coronation; contemporary sources contradict each other as to what happened on that Christmas Day in St. Peter's church. ${ }^{1}$ Charlemagne's biographer Einhard claimed that the vigorous Frankish king "would not have entered the church that day, even though it was a great feast day, if he had known in advance of the pope's plan". This became the basis for a grand narrative that survived well into the late twentieth century: that this great Germanic warrior had never wished to become emperor, but was tricked into it by a devious pope with his own agenda. Without necessarily admiring Germanicness, historians still tend to distinguish between a Frankish and Rome-freer conception of empire and a papal version thereof. ${ }^{2}$ Furthermore, the prevailing consensus has been that the imperial title was something like a cherry on Charlemagne's already plentiful cake: there is not a possibility he became a different ruler after 800 . All things considered, the great Charles could have done very well without this sudden intervention by Rome's bishop.

* Correspondence details: Mayke de Jong, Research Institute for History and Art History (OGK), Department of History and Art History, Utrecht University, Drift 6, 3512 BS, Utrecht, The Netherlands, email: m.b.dejong@uu.nl.

1 Nelson, Why Are There so Many Different Accounts; Schieffer, Neues von der Kaiserkrönung Karls des Großen. Still authoritative: Classen, Karl der Große.

2 Nelson, Kingship and Empire, 70, with reference to the distinction first made by Carl Erdmann in 843. MayrHarting, Charlemagne, the Saxons, and the Imperial Coronation. There is a long German tradition of restricting the Carolingian meaning of Romanum imperium to Rome and the papal territories. A recent example: MüllerMertens, Römisches Reich. For a pertinent critique, see Sarti, Frankish Romanness and Charlemagne's Empire, forthcoming in Speculum, October 2016. I thank the author for giving me a preview of her article. 
According to a strong and persistent trend in modern historiography, the ensuing Carolingian empire did not even last a century, and it was in a constant state of decay; almost from the very moment of its inception. Its modest glory is still exclusively associated with Charlemagne, who was the only Carolingian emperor with whom later empire builders deigned to identify with. When the Great Charles died in January 814, and his weak and overly pious son Louis succeeded, things went downhill rapidly. Or did the decay already start when the once vigorous king retired to Aachen after 800, an old emperor unable to keep his unruly daughters in check $?^{3}$ Certainly decline had well and truly started by 830 , when Louis was faced with the first of rebellions, and at the very latest it started after Louis' death in 840 and during the subsequent division of the empire among his remaining sons in $843 .{ }^{4}$ For then onwards, Carolingian imperial history was a muddle of competing members of the dynasty, so difficult to remember that it was something of a relief that the last legitimate emperor, aptly named Charles the Fat, was deposed in $888 . .^{5}$

This was the story of the Carolingian empire as I encountered it in the early 1970 s as a student of medieval history at Amsterdam University, in the extensive French, English and German bibliographies that we were expected to master. By then, the Germanic conqueror had become a patron of learning, and a champion of the heady dreams of European integration, complete with a European Karlspreis that has been awarded in Aachen since 1950. ${ }^{6}$ Otherwise, our interest in the history of Carolingian empire was minimal, for, like all medieval political history in general, it was worlds removed from the Annales-inspired cultural history that was en vogue in the 1970s. Compared to Montaillou, medieval politics seemed rather dreary and predictable, what with lay aristocrats who were always out to undermine rulers, and bishops and abbots who were not much better; they all belonged to this power-hungry elite that soon managed to wreck the Carolingian empire. In any case, as we learned from Geoffrey Barraclough, an empire was an ideal that had little to do with political reality, ${ }^{7}$ and the latter was hard to get at anyway, for all sources relevant to Carolingian political history had been produced by clerics, and were therefore far removed from the rough and tumble of actual politics.

Admittedly, well into the 1980 s this also remained my uninformed view of the matter. I must have transmitted it to students, without realising how much this gloomy perspective on Carolingian politics owed to the still authoritative publications from the late 1940s and 1950 s that I had taken on board as a student. In the aftermath of the Second World War, empire and conquest had become tainted and therefore frozen topics, along with the entire migration period and its so-called Germanic tribes. ${ }^{8}$ By the 1970 s Dutch students specialising in medieval history were either attracted by the archive-based local or regional history of the later middle ages, or, in the case of early medievalists, in French histoire des mentalités. The latter legitimated the transformation of stuffy old church history into an exciting and novel study of early medieval religion, largely inspired by cultural anthropology. It was only much

For a succinct but effective critique of the traditional view of the later Carolingian empire, see McLean, Kingship and Politics.

6 Awarded to the euro in 2002, represented by the President of the European Bank, Wim Duisenberg.

7 Barraclough, Ideal and Reality.

8 With the notable exception of Wenskus, Stammesbildung und Verfassung, a book I only came across in the 1990 . 
later, through studying Carolingian monastic ritual, in the mid-1980s, that I was confronted with the importance of monasticism for early medieval state formation; the next step was investigating the interface between early medieval religion and politics, and discovering that political history could be interesting as well as challenging. ${ }^{9}$

Around the same time, British and American historians began to break out of the restrictive framework of the rise of modern national states, showing that although early medieval kingdoms were indeed different, they did work as political communities in their own right, both at the practical and ideological level, and not just as forerunners of France or Germany. ${ }^{10}$ In order to rule, kings depended on the consensus and cooperation of their aristocracies, but the reverse also pertained: members of the elite competed for royal favour. ${ }^{11}$ That Carolingian literacy had a broader base than was hitherto assumed, had profound implications, not just for understanding the participation of lay magnates in government, but also for the realisation that the religiously articulated political discourse had not just been produced by clerics for their own consumption, or as a top-down ecclesiastical ideology to be imposed on a passive laity. ${ }^{12}$

These new approaches first and foremost focused on the Frankish kingdoms and regions, while Carolingian empire did not attract much scholarly attention. This tide started to turn around the year 2000. The upsurge of interest, which still continues, has two distinct yet complementary features. First, the predominantly Christian ideology of sempire is now taken seriously, as a force with an enduring impact outside a restricted clerical elite, and well beyond the later reign of Charlemagne and the early years of Louis. Secondly, sempirer, both in the sense of the title and the realm, is considered worth fighting for until the very end of the Carolingian dynasty. Of course the start of a new millennium has nothing to do with this revived interest in Carolingian empire, and all the more with the previous decade, which saw a fundamental shift of perspective with regard to both early medieval state formation and literacy. This opened the way for a reappraisal of the viability of this large-scale polity, also in terms of shared ideas on an imperial order that were not necessary detached from, or opposed to, spolitical reality<.

In the rest of this contribution, I will elaborate some more on these changed and changing perspectives, without claiming to offer anything like a complete historiographical survey; these comments are written from my own vantage point as a Dutch early medievalist trained in the 1970s. I then turn to the ninth century itself, and to some of the reflections on Carolingian imperium and its decay on the part of authors of the second half of that century. At the time, there were indeed voices that expressed feelings of loss and nostalgia for a glorious and peaceful Carolingian past, when augustus (either Charlemagne or Louis) still had the realm in hand. These references to an older and orderly imperial world that was lost after the division of 843 have often been cited in modern research as proof of the decline of the empire, but it was precisely during this so-called period of decay, from the 840 s onwards, that the most explicit visions of Carolingian imperium were expressed, amidst much lament about the dismal present. Division, strife and upheaval formed a powerful impetus to voice hopes and

10 Two examples that influenced my own work: Geary, Vivre en conflit; Davies and Fouracre, Settlement of Disputes.

11 Nelson, Politics and Ritual; Nelson, Frankish World. One of the first explorations of this theme: Wood and Sawyer, Early Medieval Kingship.

12 McKitterick, Carolingians and the Written Word; McKitterick, Uses of Literacy. 
aspirations for the retrieval of a lost world of united imperial rule. Whether these ideals had already been alive for earlier generations experiencing Frankish empire is a moot point, for they were not articulated as clearly as in the period of so-called decay of the Carolingian empire. All we can say is that this discourse of lost imperial unity and grandeur was very much part of the political reality of the second half of the ninth century.

\section{Kingdoms versus empire (1945-200o)}

There is no need to explain why after 1945 the Carolingian empire was no longer a popular topic of research - or any empire, for that matter. In the late 1940 s the prominent Belgian historian Francois-Louis Ganshof published some influential articles with revealing titles such as `Charlemagne's Failure`, and `The End of Charlemagne's Reign: A Decomposition<. These articles were only translated into English in 1971, which helped to secure the long-term impact of these ideas, generated in the immediate aftermath of World War II. ${ }^{13}$ Charlemagne as an imperial success-story definitely went out of favour, as did the Frankish empire as a whole. As Ganshof put it, this had been a sconception divorced from reality held by empire-minded clerics, who saw in Charles a Roman emperor God had invested with a universal magistracy for the defence and exaltation of faith and Church $\times{ }^{14}$ Despite concerted attempts, especially in capitularies issued in 802 , the imperial title gained in 800 added nothing to the usual business of Frankish kingship, and neither did it enhance relations with the papacy. ${ }^{15}$ In Ganshof's words, sthe imperial mirage, compounded of the ideas and images brought back from Rome, must have quickly dissipated when it came in contact with realities: all the more rapidly in that the concept of empire was a clerical concept, which Charlemagne himself no doubt never fully grasped.$^{16}$ His conclusion: this empire was already far along the road towards decomposition when in 814 Louis the Pious succeeded his father. ${ }^{17}$

The Belgian historian was less scathing about Louis than his Austrian colleague Heinrich Fichtenau, whose Das Karolingische Imperium (1946) painted a bleak picture of this failing ruler towards the end of his reign: 'An emperor without might or resources, a father in conflict with his sons, a pious Christian who heaped guilt on himself whenever he acted and even more so when he let things be ${ }^{18}$ Charlemagne had still been able to keep this empire in hand, but under Louis, everyone went back to a self-interested mode, most of all the so-called reformers who had seemingly adopted a monastic agenda but in fact pursued their own. In the English translation of 1957 the main title remained the same, but in fact Fichtenau distanced himself from his original theme of empire and its (im)possibilities: his last three morose chapters on imperial decline under Louis were omitted, as was an elaborate comparison with Byzantium. Instead, much on court culture under Charlemagne was added, while Aachen was no longer compared with Constantinople but discussed in relation to Jerusalem. The entire focus of the book had now shifted to Charlemagne, as a mighty king inspired by biblical models such as David and Solomon. ${ }^{19}$

Ganshof, L'échec de Charlemagne; Ganshof, Charlemagne’s Failure; Ganshof, La fin du règne de Charlemagne.

Ganshof, The Last Period of Charlemagne's Reign, 240.

5 Ganshof, The Last Period of Charlemagne's Reign, 243.

16 Ganshof, The Last Period of Charlemagne's Reign, 247.

17 Ganshof, The Last Period of Charlemagne's Reign, 250; for Ganshof's relatively benign view of Charlemagne's successor, see his Louis the Pious Reconsidered, 179-180.

18 Fichtenau, Das karolingische Imperium, 290; somewhat more optimistic: Halphen, Charlemagne et l'Empire carolingien, 305: after 840, the empire continued to exist, adapting to new circumstances.

19 Fichtenau, Carolingian Empire, transl. Munz. 
While the empire moved behind the horizon, interest in Christian kingship and its Old Testament inspiration was clearly on the rise. ${ }^{20}$ This was well received in quite different research communities that tended to operate mostly within a national context as well as separately. In German post-war medieval scholarship the snew constitutional history< (Neue Verfassungsgeschichte), a legacy from the 1930s, was still dominant. ${ }^{21}$ This meant that royal power was seen entirely as the result of the personal ability of rulers to claim the loyalty of a fickle and greedy aristocracy. Within this Personenverbandsstaat, bishops merely represented the ecclesiastical face of aristocratic family interests, and successful kings were successful lords, first and foremost. ${ }^{22}$ Without the charisma and conquests of a Charlemagne, an empire encompassing all of Latin Christianity was no more than an idea in the minds of ambitious clerics. Given the language barrier, I doubt that British historians of the 1970 s were all that familiar with this typically German brand of >othering early medieval politics, ${ }^{23}$ but through a different route, namely their openness to social anthropology, they became sensitised to the alterity of the distant past as well. Peter Brown, who moved to the United States in 1978, as well as Michael Wallace-Hadrill who remained in Oxford, are influential cases in point: they were both inspired by anthropologists such as Mary Douglas and Max Gluckman, and brought this perspective to their study of, respectively, late antiquity and the early middle ages. ${ }^{24}$ For Wallace-Hadrill and the generation he taught, be it directly or indirectly, it was Frankish kingship that mattered, not the imperial title which, it was agreed, did not affect Charlemagne's running of his vast realm in any significant way. ${ }^{25}$

These two research traditions, German and British, came together in the work of Timothy Reuter, a historian of German-English ancestry, who was familiar with current German sconstitutional historiography as well as with the anthropologically-inspired British work on early medieval social and political history. ${ }^{26}$ In 1985 , Reuter published a seminal article with immediate relevance to the theme of the empire, arguing that throughout the dynasty's history, plunder and tribute had been vital elements in the creation and consolidation of Carolingian royal power; this aggressive type of warfare had not been sustained by a general levy, but rather by a gift-economy in which rulers were dependent on the loyalty of the military elite and its war-bands. With the end of Carolingian military expansion, shortly after 800, the lack of booty made it increasingly difficult to raise such armies. The last truly aggressive campaign was Charlemagne's against the Avars (796). Under Louis the Pious, military ex-

20 Ewig, Zum christlichen Königsgedanken im Mittelalter; Schramm, Kaiser, Könige, Päpste II, 176-341, with various publications from the 1950 s on Charlemagne as king and emperor.

21 Schneidmüller, Von der deutschen Verfassungsgeschichte; Pohl, Staat und Herrschaft im Frühmittelalter.

22 See the critical appraisal of this view by Patzold, Bischöfe als Träger der politischen Ordnung; Patzold, Episcopus.

23 Pohl, Ursprungserzählungen und Gegenbilder; Pohl, Staat und Herrschaft im Frühmittelalter, 16-27. The obvious exception is Karl Leyser, but his work is much closer to the Anglophone historians inspired by social anthropology than to German traditions of institutional history.

24 Wood, John Michael Wallace-Hadrill; Wood, Modern Origins of the Early Middle Ages, ch. 15 ('The Emergence of Late Antiquity`). Wood, Transformation of Late Antiquity, to appear in Networks and Neighbours.

25 The great exception was the Austrian refugee Walter Ullmann, who became Fellow of Trinity College, Cambridge (1949) and professor of Medieval History (1972). In many ways Ullmann was part of a Continental and pre-war generation of historians of ideas, to which Percy Schramm and Ernst Kantorowicz also belonged. His grand vision of the top-down ('hierocraticı) authority of popes and emperors that supposedly dominated early medieval political structures was politely but effectively undermined by his two most prominent pupils, Janet L. Nelson and Rosamond McKitterick, who trained their own students very differently, respectively at KCL London and Cambridge University.

26 Timothy Reuter died prematurely in 2002. His collected papers have been edited by Nelson, Medieval Polities and Modern Mentalities, including Plunder and Tribute and its sequel of 1990, End of Carolingian Military Expansion. 
peditions had become purely defensive ones. By then, the super-rich Frankish empire had turned into an attractive target for plunder, and sthe very success of Frankish imperialism in the eighth century had led to a shortage of victims who were both conquerable and profitable, which forced the aristocracy to revise its profit-and-loss assessment of warfare. ${ }^{27}$ The only way out was internal expansion, that is, to say, the use of ecclesiastical property. As Reuter argued, most of Ganshof's >decomposition of the last phase of Charlemagne's reign had in fact been the result of military stagnation. Of course forgiveness and humility of the kind displayed by Louis the Pious became more desirable as resources dried up; the internal crisis of 830 were only a matter of structure and time, not of personalities or ideologies. ${ }^{28}$

This struck a chord with the mostly Anglophone historians who were exploring the early medieval past as a foreign country, ${ }^{29}$ but also with the German tradition of the Carolingian realm as Personenverbandsstaat. In Germany, also in the 1980 s, a fierce debate erupted about 'Staatlichkeit $<$ did anything of the sort exist in the Carolingian age? Johannes Fried answered this question in the negative, maintaining that ninth-century Frankish sources showed no sign of transpersonal or abstract concepts of a political community. The only possible exception was the notion of ecclesia which did seem to denote the Christian empire, but Fried dismissed this as mere >clerical thinking, far removed from actual politics. ${ }^{30}$ Hans-Werner Goetz begged to differ, countering that the concept of regnum did refer to a territorial unit that existed regardless of personal ties between a ruler and his magnates, but he as well tended to ignore the connection between ecclesia and empire, for his case was built on the Carolingian discourse on regna. ${ }^{31}$

All parties involved, including the majority outside Germany that remained unaware of the controversy on Carolingian Staatlichkeit, could accept Reuter's no-nonsense approach. It posed a welcome challenge to a version of the Carolingian empire that was still very much around in the 1980s: a rather starry-eyed notion of this splendid cultural predecessor of the current European Community, as it had been presented in 1965 during the great exhibitions on Charlemagne in Aachen, and had lived on ever since, especially in the public domain. For Reuter and many others at the time, this was mere sideology، produced by naïve modern historians and ninth-century clerics alike. Please note the negative connotation that the term Ideologie still has in German, and more in general, in a Marxist context. Economic and social structures determined the outlook of the normative sources, not the other way around.

With hindsight, the almost total absence of church and religion in these debates is striking. First and foremost, churchmen were seen as the providers of the ideology of the empire - often called the rrhetoric of reform but they were outside the hard-nosed world of politics, and if they entered it, it was as the clerical face of a self-interested aristocracy intent on countering royal attempts at centralisation. Reuter's views do raise some serious questions: was Louis the Pious really as adverse to warfare as he has been made out to be, and, more importantly, did royal/imperial control of monastic property not compensate to a large extent for the slower pace of conquest ${ }^{32}$ But by the early 1990s, when a big European-funded

32 Objections voiced at a later stage by Halsall, Warfare and Society, 91-92; see also McKitterick, Charlemagne, 135-6, 288-291. 
research programme on the Transformation of the Roman World started, Reuter's perspective on empire still prevailed, and, with some exceptions, neither religion nor the Carolingian empire occupied a central place on its agenda. ${ }^{33}$ The main themes investigated between 1992 and 1997 were the social and economic transformations between c. 400 and c. 800 , and the emergence of post-Roman kingdoms in the West with an ethnically-defined identity: 'Kingdoms of the Empirer, as the title of one of the publications of the ensuing series called it. ${ }^{34}$ Above all, this programme enabled a major confrontation between a multitude of national research traditions of which the participants had not been aware of. As it turned out, nationalism was not a thing of the past; i.e. in the early 1990s, the Yugoslav state broke up, and a series of vicious wars followed. ${ }^{35}$ And this was of course part of the collapse of a contemporary imperial state, the Soviet Union. So, in fact, weren't large empires always bound to decline and fall?

It is significant, I think, that the >Carolingian volume (c. 700-c. 900) of the New Cambridge Medieval History, published in 1995, does not feature sempire or imperium in its general index, nor in any of the chapter titles except in the one on book production. ${ }^{36}$ All the same, there are signs of change there as well. For example, in Janet Nelson's contribution, which was not on empire but on 'Kingship and Royal Government‘, a topic on which she had just published an important book, Charles the Bald (1992), which inspired younger historians to work on later Carolingian rulers and reigns. ${ }^{37}$ The notion that empire had not fundamentally changed Charlemagne's government remained in place, but plunder and tribute as the sole source of aristocratic loyalty was firmly rejected; royal control of church lands is signalled as an important alternative resource. The Carolingian empire's process of so-called dissolution, Nelson maintained, was also one of resolution and reformation; however, it did not implode. ${ }^{38}$ The year 1995 also saw the publication of a collection of articles on early medieval immunities and the ways in which these had underpinned, rather than undermined, royal resources. ${ }^{39}$ Nelson contributed to this, but also Reuter himself, who thereby helped to create a paradigm shift that went straight against his earlier work - surely the mark of a great scholar.

The overall emphasis on the otherness of early medieval societies of the 1980 s may have gone overboard a bit, but all things considered, these new approaches to the early medieval political order, inspired by anthropology and social history, provided a much-needed antidote against the anachronistic association of political history with national states or their so-called precursors. ${ }^{40}$ This in turn prepared the ground for a fresh look at the Carolingian empire. Matthew Innes' State and Society in the Early Middle Ages (2000) was the first of

33 Wood, Report. The one exception was the group concerned with >Rituals of Power , led by the archaeologist Frans Theuws, which did not think about empire, but certainly focussed on religion and the Carolingian period; see Nelson and Theuws, Rituals of Power; and De Jong et al., Topographies of Power.

34 See also Hansen and Wickham, The Long Eighth Century; Pohl, Kingdoms of the Empire; Pohl, Strategies of Distinction. The working group with the highest density of Carolingianists in it focussed primarily on political power and the rituals and topographies associated with it: Nelson and Theuws, Rituals of Power, and De Jong et al., Topographies of Power.

35 Geary, Myth of Nations.

36 McKitterick, New Cambridge Medieval History II.

37 Nelson, Charles the Bald; her translation of the main narrative of the reign of Charles the Bald was equally influential: Annales Bertiniani, trans. Nelson, Annals of St-Bertin.

38 Nelson, Kingship and Royal Government, 383-430, at 394-395; compare her earlier Kingship and Empire.

39 Davies and Fouracre, Property and Power (see n. 3 above); in a similar vein, Rosenwein, Negotiating Space.

40 See above, n. 11. 
a series of monographs with a clear (and often charter-based) focus on local and regional politics; how did the integration of such regions into political structures created by rulers and their entourages work, and how did kings gain a foothold in distant localities? ${ }^{41}$ At the beginning of the new millennium, an Austrian/German-led working group, an offspring of the European $T R W$ programme of the 1990 s, began to investigate early medieval $>$ Staatlichkeit«, a German notion impossible to translate into English or French, as it turned out, but this misunderstanding proved highly productive. $.^{42}>$ Empire was also a point of discussion, especially in relation to ecclesia as a comprehensive concept denoting a multi-ethnic polity. ${ }^{43}$

By the turn of the millennium, Carolingian imperium was definitely back on the agenda. That Johannes Fried publicly declared that Charlemagne had engineered his own imperial coronation, rather than having it foisted on him by the pope, was a sure sign that the mood was changing, even in Germany. ${ }^{44}$ In two major syntheses published in 2005, by Chris Wickham and Julia Smith; empire is largely absent; ${ }^{45}$ its return on the scholarly agenda seems to have been the work of a younger generation. Simon MacLean's study of the last Carolingian emperor, Charles the Fat, reveals the extent to which older historiography had gotten stuck in the paradigm of an empire that was always decaying, awaiting the rise of nations; MacLean also shows how important the imperial title was for competing members of the later Carolingian dynasty. ${ }^{46}$ In a similar vein, Eric J. Goldberg entitled his monograph on Louis the German Struggle for Empire. ${ }^{47}$ In that same year, Steffen Patzold deconstructed the tenacious idea that in the 830 s a clerical Reichseinheitspartei had unrealistically persisted in keeping the ideal of empire intact, in the face of very different political realities of a more Germanic kind. For Patzold (and myself, for that matter) churchmen and lay magnates alike shared a religiously articulated sense of 'ministry and service to a public cause embodied by royal and imperial authority; whenever this corporate identity was threatened, the ensuing fissure did not simply run along the time-honoured lay/clerical divide. ${ }^{48}$ My own book on religious/ political discourse during the reign of Louis the Pious (2009) assumed the importance of an rempire as ecclesia as a matter of course: by the early ninth century, the Old Testament notion of the Franks as the elect, a people that had replaced the prior populus, Israel, was difficult to maintain, and the ecclesia gentium offered a suitable alternative model for identification. ${ }^{49}$ But I wish I had shown even more that humility and atonement were typically imperial virtues, and the same could be argued for another of Louis' public virtues once thought of as a private weakness, namely clemency. ${ }^{50}$

The Carolingian World, an excellent textbook produced in 2011 by three prominent pupils of McKitterick and Nelson, shows how rapidly thinking on rempire has changed. ${ }^{51}$ It contains an extensive chapter on sInventing the Carolingian empire, 800-840<, which takes

41 Innes, State and Society; Innes, People, Places and Power.

42 Airlie et al., Staat im frühen Mittelalter; Pohl and Wieser, Der frühmittelalterliche Staat.

43 De Jong, Ecclesia and the Early Medieval Polity.

44 Fried, Papst Leo III. besucht Karl den Großen; see also Fried, Karl der Große.

45 Wickham, Framing the Early Middle Ages; Smith, Europe after Rome.

46 MacLean, Kingship and Politics.

47 Goldberg, Struggle for Empire.

48 Patzold, Eine »loyale Palastrebellion«; a divide also broken down in Wormald and Nelson, Lay Intellectuals.

49 De Jong, Empire as Ecclesia.

50 De Jong, Penitential State.

51 Costambeys et al., Carolingian World, 154-222. 
into account Reuter's views, but concludes that the cessation of wars of conquest in the early 800 rcatalysed a dramatic shift in this culture which meant the roles of every member of the elite, from the royal family had to be redefined. The term empire shad to be invented in the imaginations and mentalities of its elites.${ }^{52}$ The familiar mantra that the imperial coronation did not radically alter Charlemagne's rule is reiterated, yet the emphasis is on the greater intensity of the ruler's attempts at effective control, from 802 onwards. ${ }^{53}$ As to its success, the answer is fairly positive and a far cry from Ganshof's theory of decomposition and Reuter's theory of military collapse of the empire. Hard on the heels of this already influential synthesis, in 2012 Martin Gravel published an extensive investigation of how the Carolingian empire really worked, under Charlemagne and Louis, with upbeat conclusions on the effectiveness of communication between these rulers and their elites, both lay and ecclesiastical, central and peripheral. The subtitle speaks for itself: Réaliser l'empire sous Charlemagne et Louis le Pieux. Gravel's sources have been known to known to historians since Ganshof wrote about Charlemagne's failure, yet his interpretation of them is entirely different..$^{54}$

New work on the Carolingian empire keeps appearing. Some of it remains focused on its ideological aspects, but without having to apologise for ideals that are clerical and therefore far removed from political reality; the topics recently explored range from a re-examination of the expression imperium ${ }^{55}$ and rempires as a Christian community writ large ${ }^{56}$ to the impact of Carolingian notions of sempires on later centuries. ${ }^{57}$ At the same time, the practical side of imperial power and authority has become a central concern to the point of moving centre stage. ${ }^{58}$ As I wrote most of this paper in August 2015, Jennifer R. Davis' new book appeared: unfortunately too late for me to take it on board here. But its title speaks volumes: Charlemagne's Practice of Empire. ${ }^{59}$

\section{Carolingian empire and decay: some contemporary voices}

The overall image we are left with, after two decades of research, is one of a Carolingian world in which rulers and their leading men shared a strong sense of order, and the determination to implement this in the real world. Conflict was as much a regular feature of ninth-century politics as consensus, and it was behind much of the more articulate reflections on the nature and cohesion of the polity. Bishops and abbots were very much part of the governing elite, controlling lands that were essential to the military survival of the state. ${ }^{60}$ According to ninth-century usage, imperium did not so much refer to a clearly-defined territorial unit as to the exercise of imperial authority by the senior member(s) of the Carolingian dynasty who bore the title augustus imperator. It was the unanimity between Louis and his sons, including his co-emperor Lothar,

52 Costambeys et al., Carolingian World, 159-160.

53 Already signalled in Innes, Charlemagne’s Government.

54 Gravel, Distances, rencontres, communications. For some groundbreaking recent work on early medieval literacy, see Brown et al., Documentary Culture and the Laity.

55 Van Espelo, Testimony of Carolingian Rule; Sarti, Frankish Romanness (see above, footnote 2).

56 Patzold, "Einheit« versus "Fraktionierung«; Phelan, Formation of Christian Europe; Kramer, Great Expectations.

57 Latowsky, Emperor of the World.

58 Notably Gravel, Distances, rencontres, communications, but also Garipzanov, Symbolic Language of Royal Authority, with a strong focus on images of empire circulating via coins and other publicly accessible media. And, very recently, Conant, Louis the Pious.

59 About to appear with Cambridge University Press.

60 De Jong, Ecclesia and the Early Medieval Polity. On the pre-Carolingian period, see Wood, Entrusting Western Europe to the Church. 
that was at stake in 830-833, not the sunity of empirer (Reichseinheit) ${ }^{61}$ In the territorial sense of the word, this empire ended where the correct Christian cult was no longer practiced. Its boundaries were liturgical as well as political: the right kind of baptismal rite determined membership of the political community. ${ }^{62}$ At the very heart of what we call the Carolingian empire was the ruler's protection of a divinely sanctioned cultus divinus, and his duty to extend and enforce this within the boundaries of Christianity under Frankish imperial rule.

This Christian-imperial discourse is not very evident during Charlemagne's reign; it only fully emerged under Louis the Pious, and only really came into its own after 840 , when according to traditional modern historiography, the decline of empire was already a fact. The ninth-century imperial discourse lent plenty of support to modern grand narratives about the decline of empire, for apart from triumphalist voices it also features dire complaints about the loss of unity and moral purpose that had once existed. The latter are best understood as witnesses to a growing awareness of what a united Christian polity and its leadership should be like, with ideas that were further articulated through the series of dynastic crises that started in the early 830 .

In the narrative sources in question, the expressions regnum and imperium were often used interchangeably, as is the case in a brief but celebrated reference to the Carolingian empire: the opening sentences to the Gesta Karoli written by the monk Notker from St. Gall, sometime between 885 and 887 , very shortly before the last emperor's deposition in $888 .{ }^{63}$ Notker had no idea of what was coming, so his adaptation of King Nebuchadnezzar's dream (Daniel 2, 36) is unabashedly imperialist, even though he wrote consistently about regnum, rather than imperium. After having smashed the lead and clay statue that symbolised the previous four world powers, including the Roman Empire, God had created another with the Carolingians at its head. Charlemagne represented the golden head of a second and no less remarkable statuer, a Frankish empire of which the Greeks and Romans were of course greatly envious. ${ }^{64}$ Notker meant the Byzantines, and the inhabitants of the city of Rome; whereas the latter habitually opposed anyone of importance connected to the apostolic see,${ }^{65} \mathrm{Charles}$ was the Defender of the Church of Rome. This text certainly had eschatological overtones, ${ }^{66}$ but it was also very much part of a highly concrete and terrestrial Frankish imperial imagination in which Charlemagne took >Persian envoys hunting and proved his superiority. ${ }^{67}$ The very fact that the death and the name of the elephant Abul Abbas, the gift of a fellow emperor from the East, were recorded in the Royal Frankish Annals of 810, makes it clear that imperium was not just an idea connected with the end of times. This was about interimperial one-upmanship involving organs and impressive beasts, symbols of the complementary world rule of Franks, Greeks and Persians. The latter referred to the imperial aspect of the caliphate. However, if Muslims from Spain attacked Franks, they were called Saracens.

A less known but equally strident statement of Frankish imperialism comes from Hraban Maur (d. 856), who as abbot of Fulda got into conflict with his monk and one-time child oblate Gottschalk. In 829 the latter had refused to recognise the validity of his oblation ritual, on

61 Patzold, Eine »loyale Palastrebellion«.

62 Reimitz, Grenzen und Grenzüberschreitungen.

63 See MacLean, Kingship and Politics, 199-229, with references to older literature.

64 Notker, Gesta Karoli I, cc. 1.10, ed. Haefele 1,12.

65 Notker, Gesta Karoli I, c. 26, ed. Haefele, 34-35.

66 Nelson, Kingship and Empire, 72.

67 Notker, Gesta Karoli II, c. 8, ed. Haefele, 59. 
the grounds that only Frankish witnesses had been present, not Saxon ones. Protesting about this to the Emperor Louis and his entourage, Hraban maintained that the Saxons had been conquered and then converted by the Franks. As newcomers to Christianity, they had no right to reject Frankish witnesses; throughout history, under the Persians as well as the Romans, the conquered gentes had obeyed imperial rule. As the successor of Roman imperium, Frankish rule deserved a similar respect. ${ }^{68}$ In his prolific exegesis, Hraban wrote about many biblical kings in imperial terms, for they governed many peoples; Queen Esther, likened to Louis's wife, the Empress Judith, was a case in point. Esther's husband, King Ahasveros, was an imperial figure because of his multi-ethnic realm. ${ }^{69}$

This was the Carolingian empire as in ruling a multitude of converted gentes drawn into the Frankish/Christian fold, but it could also mean the Saxons were becoming an integral part of the Frankish populus, as Einhard expressed it. The terminology remained fluid. Einhard is an interesting witness to empire, precisely because his remark that Charlemagne would never have entered St Peter's Basilica on Christmas Day 800, had he known what would hit him, has so often been invoked as proof of some kind of Frankish ambivalence about the imperial title. Humility was one of the key virtues of late antique Christian emperors, however, and in other respects as well, Einhard's Vita Karoli is an eloquent testimony to imperial rule: Charlemagne is portrayed as lending his support to the Christians of the East, including Jerusalem, Alexandria and Carthage. ${ }^{70}$ Not only did he order the codification of the laws of all the nations under his rule, he also had old songs in his mother tongue written down, started on a grammar in his native language and used this to rename the months and the winds; how imperial can one get? Notwithstanding Einhard's consistent use of regnum Francorum in his post-800 narrative, his is a portrait of truly imperial greatness. ${ }^{71}$

Einhard's brilliant literary experiment, with its subtle use of Suetonius' biography of Augustus should not blind us to the fact that the model empire of the past was not so much ancient pagan Rome, but its late antique and Christian successor that came into existence in 313. This world of Constantine, and above all of Theodosius and Ambrose, provided ideal imperial history to Frankish authors. Given that this was also the age of the Fathers - Jerome, Ambrose and Augustine - upon which Carolingian biblical exegesis was built, this Christian imperial past functioned much like biblical history: as an imagined community that constantly impinged on the present. When it comes to assessing ninth-century complaints about >decay of empirer, it should be kept in mind that these two yardsticks, biblical and late antique-imperial, underpinned all judgements of decline in the more recent Carolingian past, and often were thought more fundamental than contemporary history. The crucial question in political reflection was, where and when did we fall short of these illustrious examples? One defence of Louis's repeated public penances was that he had been >like Theodosius`; one of his detractors called him Ahab, incapable of mastering his Jezebel/Judith. ${ }^{72}$

68 Hraban, Liber de oblatione puerorum, PL 107, cols. 432A-442C; De Jong, State of the Church, 251; Patzold, Hraban, Gottschalk und der Traktat.

69 De Jong, Exegesis for an Empress.

70 Einhard, Vita Karoli, c. 27, ed. Holder-Egger, 31.

71 McKitterick, Charlemagne, 7-20, with the arguments for an early dating; for a later one, see Patzold, Einhard's erste Leser; Ganz, Einhard's Charlemagne.

72 De Jong, Penitential State, 122-4, 128-30, 229 
This authoritative imperial past did not emerge overnight on Christmas Day 800. The building blocks were there, of course, but erecting the entire edifice took time. The process itself has recently and aptly been summed up under the heading of slearning empire.$^{73}$ Hence, it is not surprising that an eloquent statement about empire such as Notker's dates from what modern historians deemed to be the very end of the Carolingian imperium. The discourse of empire in terms of ecclesia was initiated by biblical scholars such as Hraban, and embraced by those who drafted Louis' capitularies and conciliar acts, but it only really took off after this emperor's death in 840 and the ensuing struggle for the empire among his three remaining sons. The battle of Fontenoy in June 841 became a traumatic watershed: many leading Franks died on the battlefield in a way still prevented in 833. By then it was also clear that the three remaining heirs of Louis were not going to rule in unison. ${ }^{74}$ The first references to this lost world, perhaps infused with nostalgia but still very real to the political actors turned authors who had been part of it, date from the 840 and 850s. The Astronomer's Life of Louis, a work written by a member of Louis' inner circle shortly after 840 is one example; Nithard's trenchant report on the strife between Louis's sons in $840-843$ is another. The latter author was a well-educated lay magnate, a member of the Carolingian family, who wrote at the behest of Louis' son Charles the Bald. Dhuoda's celebrated handbook for her son William in 841 when he joined this king's court should also be mentioned: a central issue in this text, as in Nithard's, is the nature of fides, the ideal of true loyalty to God and one's ruler, which was under threat and needed to be reaffirmed. ${ }^{75}$ For the Astronomer and Nithard alike, imperium was a key concept, not as a territorial notion but as the joint authority of those participating in imperial rule. Another expression full of meaning used by both these authors was publicus: this was the domain of the Carolingian commonwealth, the res publica. This was opposed to anything that was privatus - the deprived and immoral world of those who pursued their own interests. ${ }^{76}$ Political and personal animosity were behind Nithard's terse and classically-inspired prose, but his is as clear a statement as any about a severely challenged world of Carolingian suniversal empire (universum imperium) as he called it. ${ }^{77}$

These are by no means the only narratives produced after Louis's death in 840 that tried to come to terms with the dynastic upheaval during and shortly after this emperor's reign. ${ }^{78}$ The most interesting text, on which I can comment only briefly on here, is the Epitaphium Arsenii by Paschasius Radbertus (d. 860)..$^{79}$ This monk and one-time abbot of Corbie and one of the most gifted biblical commentators of his day and age, also wrote funeral orations for his illustrious mentors and predecessors, Adalhard and Wala. The former was nicknamed Antony, the latter Arsenius, names chosen by their inner circles at the court and in Corbie from the authoritative past of imperial Christianity. These cousins of Charlemagne became great abbots after an equally illustrious secular career. As in the case of Nithard's Histories,

73 Gantner et al., Resources of the Past, see the introduction by Walter Pohl. On cultural memory and the construction of a Frankish notion of empire in ninth-century historiography see McKitterick, History and Memory.

74 Nelson, The Search for Peace.

75 De Jong, Carolingian Political Discourse, with reference to other relevant publications (notably by Janet L. Nelson and Régine Le Jan).

76 Depreux, Nithard et la Res Publica; Nelson, Public Histories and Private History (repr. in Nelson, Politics and Ritual, 195-237); Airlie, The World, the Text and the Carolingian.

77 Nithard, Historiae, I, c. 2, ed. Pertz, 3.

78 C.f. Booker, Past Convictions, on ninth-century texts as pegs for later narratives of decline.

79 A text on which I am presently finishing a book: Epitaph for an Era, to appear with Cambridge University Press. 
Radbert's Epitaphium Arsenii had a huge impact on modern views of the decline of the Carolingian empire, yet the diffusion of these texts in their own day and age was extremely limited. ${ }^{80}$ These were works written for a restricted and court-connected circle, including rulers. Their authors felt marginalised and protested to those in power, appealing to their peers and invoking the values that all those connected to the Carolingian dynasty still shared, whatever the political turbulence and conflicting loyalties of the present.

In this context of post-Fontenoy soul-searching, conceptions of empire further evolved. With authors such as the Astronomer, Nithard and Radbert, there is sometimes a territorial dimension to imperium, but often this concept refers to the imperial exercise of authority, under the aegis of an imperator. ${ }^{81}$ Radbert consistently called Louis the Pious >Caesar or >Augustus<. The second book of the Epitaphium was written two decades after the first, in the mid-850s, and is mostly about the role of Charlemagne's cousin, Abbot Wala of Corbie (nicknamed Arsenius by his monks) in the two rebellions against Louis. Wala's pupil Radbert defended his master strenuously after the latter's death in 836 , and he had much to say about Wala's struggle for the unity of the sentire empires, in the sense of the joint imperial rule of Louis and his eldest son Lothar that had been torn apart by conflict. ${ }^{82}$ Lothar had been his father's co-emperor since 817, a truly imperial configuration that had been initiated by Charlemagne in 813 , when, one year before his death, he made his only remaining son Louis a co-emperor. In Radbert's discourse, imperium and regnum are complementary and even overlapping concepts, as transpires from enumeration of Wala's motives for getting involved in the rebellion of 830:

"For there is nobody so insane that he would call it a sin to act with sacred counsel, for fidelity, for the life of Caesar, for the sons and imperial rule (imperio), for the salvation of the people and the deliverance of the fatherland, for the justice and laws of the emperors (augusti), for the stability and unity of the kingdom (regnum), and the concord of peace, for the averting of vices and abominations, because of adultery, which is the worst of these, and because of the abuse of the entire empire (imperium). « $^{83}$

This is just one of many instances in which regnum and imperium have much more than a purely territorial connotation. Radbert, who had been deposed as Corbie's abbot by the time he penned his polemical second book in the 850 s, lamented a world of imperial unity he had lost, but this unity was above all the unanimity of the Carolingian rulers and their leading

80 My most recent publication on the Epitaphium Arsenii, with references to older literature, is titled Jeremiah, Job, Terence and Paschasius Radbertus. On the transmission of Nithard's Histories, see Booker, Early Humanist Edition of Nithard. Radbertus' Epitaphium Arsenii is only extant in one Corbie manuscript, BN 13909, which may have been corrected by the author himself.

81 See Ernst Tremp's edition of Thegan's Gesta Hludowici, and Astronomer, Vita Hludowici, with an excellent index which shows in one glance that Louis was very much an imperator, but that the imperium of which modern historians were in search, plays a minor part. The same holds true for the Epitaphium Arsenii: Louis is always referred to, consistently, Caesar or Augustus, but imperium denotes his rule, shared or not with his sons.

82 Paschasius Radbertus, Epitaphium Arsenii, II, c. 10, ed. Dümmler, 76: >Voluit ut unitas et dignitas totius imperii maneret ob defensionem patriae et ecclesiarum liberationem, ob integritatem rerum, et dispensationem facultatum ecclesiarum: nunc autem, ut cernimus, omnia sunt immutata vel perturbatar.

83 Paschasius Radbertus, Epitaphium Arsenii, II, c. 11, ed. Dümmler, 78: `Quia nemo tam insanus mente, qui peccatum dicat agere sancto consilio, pro fide, pro vita Caesaris, pro filiis et imperio, pro salute populi, et salvatione patriae, pro justitia et legibus Augustorum, pro stabilitate et unitate regni, pacisque concordia, pro depulsione vitiorum et abominationum, pro adulterio, quod ultimum est, et pro contumelia totius imperii<. 
men, referred to by Radbert as the senatus or senatores.$^{84}$ Like Nithard's Histories, this was a partisan narrative; the second book fiercely defended Wala's good intentions in the uprising of 830, and his fundamental loyalty to his emperor, Louis. Yet behind this recent and traumatic struggle for empire there was another, more important past: the late antique Christian empire. By using transparent aliases for his political protagonists, such as Justinian (Louis), Justina (Judith), Honorius (Lothar) and so on, this author deftly evoked an authoritative imperial past. Implicitly, Wala was likened to Ambrose facing up to Theodosius, but since the great man was a onetime general, but never a priest or bishop, a direct comparison with the bishop of Milan would not have been appropriate. Instead, Wala received the byname 'Arsenius«, after the tutor to Theodosius' son Honorius who, according to tradition, exchanged the imperial court for a monastic life.$^{85}$ Equally deliberate, Louis was denied the honorific alias of Theodosius, probably as a reaction to other authors who, loyal to the old emperor, compared his public atonement of 822 to Theodosius' exemplary penance in $391 .{ }^{86}$ Instead, in the Epitaphium Louis became Justinian I, a ruler with a questionable reputation, both as a supporter of heresy and a despoiler of church property.

Obviously, these aliases were intended for a small audience of insiders who knew their Christian imperial history as well as their biblical past, but this select group did not merely consist of monks of Corbie. The issues raised by Radbert in the Epitaph's second book were relevant to all those who had been caught up in the political whirlwinds of the early 830s, and were still debating the meaning of it all two decades later. Clearly the fact that Louis had been an emperor, and that they had served under imperial rule, mattered deeply. By the mid850s, when Radbert added his second book, his ruler was Charles the Bald, a king (rex) who had started well with regard to protecting monasteries such as Corbie, but who had been found wanting in the long run. ${ }^{87}$ The imperial unity of the past had been lost because nobody at the time had listened to Wala's dire warnings, with the result that sup to the present day, none of the rulers can show the commonwealth the way towards justice.$^{88}$ So this text was indeed an repitaph for an erar, yet it is also one of the most articulate statements about what imperial rule should entail. This largely overlapped with the ecclesia, but the question was how to keep the two orders within it apart. The secular and the clerical domain should remain distinct, so that they would be able to operate in a complementary mode. Without this distinction, there would be no co-operation under the aegis of a legitimate monarch, who allowed himself to be advised by the likes of Wala, an expert on the way in which imperial rule worked. He had even managed to counter corruption in Italy! This is Rabert's message in his funeral oration for a man who is presented as the epitome of service to the augusti of his day and age.

84 Paschasius Radbertus, Epitaphium Arsenii, II, c. 1, ed. Dümmler, 61: Inde ad comitatum rediens, omnia coram augusto et coram cunctis ecclesiarum praesulibus et senatoribus proposuit singillatim diversorum ordinum officia, excrescentibus malis, et ostendit cuncta esse corrupta vel depravatar.

85 De Jong, Becoming Jeremiah.

86 Astronomer, Vita Hludowici, c. 35, ed. Tremp, 406.

87 Paschasius Radbertus, Epitaphium Arsenii, II, c. 4, ed. Dümmler, 65.

88 Paschasius Radbertus, Epitaphium Arsenii, II, c. 6, ed. Dümmler, 66. 


\section{Conclusion}

In modern scholarship, the Epitaphium Arsenii has become one of the key witnesses to the view that decline of the Carolingian empire set in with the crisis of Louis' reign; Einhard's Vita Karoli served as the peg for another invented tradition, closely associated with the Kulturkampf and the late nineteenth century, according to which Charlemagne would have avoided the empire and the ensuing connection with papal Rome, had he known what was coming. Ninth-century narratives and normative texts have offered plenty of footholds for modern historians who saw the decay of empire everywhere, or who deemed the imperial title superfluous to Charlemagne's already successful rule. He was the only Carolingian emperor that continued to have a real impact on European memory. After him it all went downhill, for a very long time. Yet the very sources that once underpinned this gloomy view of Carolingian empire, now support a much more upbeat approach to this phenomenon. Investigating this topic therefore needs to be a dual operation: studying early medieval sources in conjunction with their subsequent layers of modern interpretation.

In this rather impressionist paper I have sketched some of the changes that occurred since 1945, when those who had lived through World War II were understandably not very enthusiastic about rempire and all that it stood for. Post-war scholarship on the Carolingian period reveals a constant tension between a modernising perspective, which soon becomes anachronistic if pushed to its extremes, and archaising tendencies that turn the early Middle Ages into an exotic and utterly foreign country. This tension has proven fruitful, provided those involved are aware of it, a tenet that also holds true for research on the Carolingian empire. It is nowadays conducted by a generation that has found a new balance between the modernity and otherness of this period, and no longer has to write about empire in terms of dichotomies: ideal versus reality, or clerical ideology versus aristocratic power. This is a past which does seem like a foreign country at first, but getting to know it is not entirely impossible. 


\section{References}

Airlie, Stuart, Pohl, Walter, and Reimitz, Helmut (eds.), Staat im frühen Mittelalter. Forschungen zur Geschichte des Mittelalters 11 (Vienna, 2006).

Airlie, Stuart, The World, the Text and the Carolingian: Aristocratic and Masculine Identities in Nithard's Histories, in: Patrick Wormald and Janet L. Nelson (eds.), Lay Intellectuals in the Carolingian World (Cambridge, 2007) 51-77.

Astronomer, Vita Hludowici imperatoris, ed. Ernst Tremp, MGH SS rerum Germanicarum in usum scholarum seperatum editi [64] (Hanover, 1995).

Barraclough, Geoffrey, The Mediaeval Empire: Ideal and Reality (London, 1950).

Booker, Courtney M., An Early Humanist Edition of Nithard, De dissensionibus filiorum Ludovici Pii, Revue d'histoire des textes 5 (2010) 231-258.

Brown, Warren C., Costambys, Marios, Innes, Matthew and Kosto, Adam J. (eds.), Documentary Culture and the Laity in the Early Middle Ages (Cambridge, 2013).

Booker, Courtney M., Past Convictions: The Penance of Louis the Pious and the Decline of the Carolingians (Philadelphia, 2009).

Classen, Peter, Furhmann, Horst, and Märtl, Claudia (eds.), Karl der Große, das Papsttum und Byzanz. Die Begründung des karolingischer Kaisertums, Beiträge zur Geschichte und Quellenkunde des Mittelalters 9 (Sigmaringen, 1985).

Conant, Jonathan P., Louis the Pious and the Contours of Empire, Early Medieval Europe 22 (2014) 336-360.

Costembeys, Marios, Innes, Matthew and McLean, Simon (eds.), The Carolingian World (Cambridge, 2011).

Davies, Wendy, and Fouracre, Paul (eds.), The Settlement of Disputes in Early Medieval Europe (Cambridge, 1986).

Davies, Wendy, and Fouracre, Paul J. (eds.), Property and Power in the Early Middle Ages (Cambridge, 1995).

Davis, Jennifer R., Charlemagne's Practice of Empire (Cambridge ) forthcoming.

Depreux, Philippe, Nithard et la Res Publica: un regard critique sur le règne de Louis le Pieux, Médiévales 22-23 (1992) 149-161.

Einhard, Vita Karoli, ed. Oswald Holder-Egger, MGH SS rerum Germanicarum [25] (Hanover 1911).

Espelo, Dorine van, A Testimony of Carolingian Rule? The Codex epistolaris Carolinus, its Historical Context, and the Meaning of imperium, Early Medieval Europe 21 (2013) 254-282.

Ewig, Eugen, Zum christlichen Königsgedanken im Mittelalter, in: Das Königtum. Seine geistigen und rechtlichen Grundlagen. Mainauvorträge 1954, Vorträge und Forschungen 3 (Lindau, 1956) 7-73.

Fichtenau, Heinrich, Das karolingische Imperium. Soziale und geistige Problematik eines Grossreiches (Zürich, 1949).

Fichtenau, Heinrich, The Carolingian Empire, trans. Peter Munz (Toronto, 1957).

Fried, Johannes, Der karolingische Herrschaftsverband im 9. Jh. zwischen "Kirche" und "Königshaus", Historische Zeitschrift 235 (1982) 1-43.

Fried, Johannes, Gens und regnum. Wahrnehmungs- und Deutungskategorien politischen Handels im früheren Mittelalter. Bemerkungen zur doppelten Theoriebindung des Historikers, in: Jürgern Miethke and Klaus Schreiner (eds.), Sozialer Wandel im Mittelalter. Wahrnehmungsformen, Erklärungsmuster, Regelungsmechanismen (Sigmaringen 1994) 73-104. 
Fried, Johannes, Papst Leo III. besucht Karl den Großen in Paderborn oder Einhards Schweigen, in: Historische Zeitschrift 272 (2001) 281-326.

Fried, Johannes, Karl der Große: Glaube und Gewalt (München, 2013).

Ganshof, François-Louis, L'échec de Charlemagne, Académie des Inscriptions et Belles Lettres. Comptes Rendus des scéances 91 (1947) 248-254.

Ganshof, François-Louis, Louis the Pious Reconsidered, in: François-Louis Ganshof (ed.), The Carolingians and the Frankish Monarchy (London, 1971) 261-272, originally published in History 42 (1957) 171-180.

Ganshof, François-Louis, Charlemagne's Failure, in: François-Louis Ganshof (ed.), The Carolingians and the Frankish Monarchy: Studies in Carolingian History (London, 1971) 256-259.

Ganshof, François-Louis, La fin du règne de Charlemagne. Une décomposition, Zeitschrift für Schweizerische Geschichte 28 (1948) 533-552, transl. The Last Period of Charlemagne's Reign; a Study in Decomposition, in: Ganshof, The Carolingians and the Frankish Monarchy, 240-255.

Gantner, Clemens, McKitterick, Rosamond, and Meeder, Sven (eds.), The Resources of the Past in the Early Middle Ages (Cambridge, 2015).

Ganz, David, Einhard's Charlemagne: the Characterization of Greatness, in: J. Story (ed.), Charlemagne, Empire and Society (Manchester, 2005) 38-51.

Garipzanov, Ildar, The Symbolic Language of Royal Authority in the Carolingian World (c.751877) (Leiden, 2008).

Geary, Patrick J., Vivre en conflit dans une France sans état: Typologie des méchanismes des règlements des conflits, 1050-1200, Annales ESC 41 (1986) 1107-1133, transl. in Patrick J. Geary (ed.), Living with the Dead in the Middle Ages (Ithaca, 1994).

Geary, Patrick J., The Myth of Nations. The Medieval Origins of Europe (Princeton, 2001).

Goetz, Hans-Werner, Regnum. Zum politischen Denken der Karolingerzeit, Zeitschrift der Savigny-Stiftung für Rechtsgeschichte, Germanistische Abteilung 104 (1987) 110-189.

Goldberg, Eric J., Struggle for Empire: Kingship and Conflict under Louis the German, 817-876 (Ithaca, 2006).

Gravel, Martin, De la crise du règne de Louis le Pieux. Essai d'historiographie, Revue historique 313/2 (2011) 357-358.

Gravel, Martin, Distances, rencontres, communications. Réaliser l'empire sous Charlemagne et Louis le Pieux. Collection Haut Moyen Age 15 (Turnhout, 2012).

Halphen, Louis, Charlemagne et l'Empire carolingien (Paris, 1949).

Halsall, Guy, Warfare and Society in the Barbarian West, 450-90o (London, 2003).

Hansen, Inge Lyse, and Wickham, Chris (eds.), The Long Eighth Century: Production, Distribution and Demand (Leiden, 2000).

Hraban, Liber de oblatione puerorum, ed. Jaques-Paul Migne, PL 107 (Paris, 1864).

Innes, Matthew, State and Society in the Early Middle Ages (Cambridge, 2000).

Innes, Matthew, People, Places and Power in Carolingian Society, in: de Jong et al., Topographies of Power in the Early Middle Ages, 397-439.

Innes, Matthew, Charlemagne's Government, in: Joanna Story (ed.), Charlemagne: Empire and Society (Manchester, 2005) 71-89.

Jong, Mayke de, Carolingian Monasticism: The Power of Prayer, in: McKitterick, New Cambridge Medieval History II, 622-653.

Jong, Mayke de, The Foreign Past: Medieval Historians and Cultural Anthropology, Tijdschrift voor Geschiedenis 109 (1996) 323-339. 
Jong, Mayke de, The Empire as ecclesia: Hrabanus Maurus and Biblical historia for Rulers, in: Yitzhak Hen and Matthew Innes (eds.), The Uses of the Past in the Early Middle Ages (Cambridge, 2000) 191-226.

Jong, Mayke de, Theuws, Frans, and Rhijn, Carine van, Topographies of Power in the Early Middle Ages (Leiden etc., 2001).

Jong, Mayke de, Exegesis for an Empress, in: Esther Cohen and Mayke de Jong (eds.), Medieval Transformations: Texts, Power and Gifts in Context (Leiden, 2001) 69-100.

Jong, Mayke de, Becoming Jeremiah: Radbert on Wala, Himself and Others, in: Rosamond McKitterick, Irene van Renswoude, Matthew B. Gillis and Richard Corradini (eds.), Ego Trouble: Authors and their Identities in the Early Middle Ages. Forschungen zur Geschichte des Mittelalters 15 (Vienna, 2010) 185-196.

Jong, Mayke de, Ecclesia and the Early Medieval Polity, in: Airlie et al., Staat im frühen Mittelalter, 113-132.

Jong, Mayke de, The Penitential State: Authority and Atonement in the Age of Louis the Pious (Cambridge, 2009).

Jong, Mayke de, The State of the Church: Ecclesia and Early Medieval State Formation, in: Pohl and Wieser, Der frühmittelalterliche Staat, 241-254.

Jong, Mayke de, Carolingian Political Discourse and the Biblical Past: Hraban, Dhuoda, Radbert, in: Gantner et al., 293 Resources of the Past, 87-102.

Jong, Mayke de, Jeremiah, Job, Terence and Paschasius Radbertus: Political Rhetoric and Biblical Authority in the Epitaphium Arsenii, in: Jinty Nelson and Damien Kempf (eds.), Reading the Bible in the Middle Ages (London, 2015) 57-76.

Jong, Mayke de, Epitaph for an Era: Paschasius Radbertus and his Lament for Wala (forthcoming). Kramer, Rutger, Great Expectations: Imperial Ideologies and Ecclesiastical Reforms from Charlemagne to Louis the Pious (813-822). Unpublished PhD thesis (Freie Universität Berlin, 2014).

Latowsky, Anne, Emperor of the World: Charlemagne and the Construction of Imperial Authority (Ithaca, 2013).

MacLean, Simon, Kingship and Politics in the Late Ninth Century: Charles the Fat and the End of the Carolingian Empire (Cambridge, 2003).

Mayr-Harting, Henry, Charlemagne, the Saxons, and the Imperial Coronation of 800, English Historical Review 111 (1996) 1113-1133.

McKitterick, Rosamond, The Carolingians and the Written Word (Cambridge, 1989).

McKitterick, Rosamond (ed.), The Uses of Literacy in Early Medieval Europe (Cambridge, 1990).

McKitterick, Rosamond (ed.), The New Cambridge Medieval History II c. 700 -c. 900 (Cambridge, 1995).

McKitterick, Rosamond, History and Memory in the Carolingian World (Cambridge, 2004).

McKitterick, Rosamond, Charlemagne: The Formation of a European Identity (Cambridge, 2008).

Müller-Mertens, Eckhard, Römisches Reich im Frühmittelalter: kaiserlich-päpstliches Kondominat, salischer Herrschaftsverband, Historische Zeitschrift 288 (2009) 51-92.

Nelson, Janet L., Politics and Ritual in Early Medieval Europe (London, 1986).

Nelson, Janet L., Public Histories and Private History in the Work of Nithard, Speculum 60 (1985) 251, repr. in Nelson, Politics and Ritual, 195-237.

Nelson, Janet L., Kingship and Empire, in: James Henderson Burns (ed.), The Cambridge History of Medieval Political Thought, c. 350-c. 1450 (Cambridge, 1988) 211-251.

Nelson, Janet L., The Annals of St-Bertin: Ninth-Century Histories 1, translated and annotated by Janet L. Nelson (Manchester, 1991).

Nelson, Janet L., Charles the Bald (London, 1992). 
Nelson, Janet L., Kingship and Empire in the Carolingian World, in: Rosamond McKitterick (ed.), Carolingian Culture: Emulation and Innovation (Cambridge, 1994) 52-87.

Nelson, Janet L., Kingship and Royal Government, in: McKitterick, New Cambridge Medieval History II, 383-430.

Nelson, Janet L., The Frankish World 750-90o (London, 1996).

Nelson, Janet L., The Search for Peace in a Time of War: The Carolingian Brüderkrieg, 840843, in: Johannes Fried (ed.), Träger und Instrumentarien des Friedens im hohen und späten Mittelalter, Vorträge und Forschungen 43 (Sigmaringen, 1996) 87-114.

Nelson, Janet L., Women at the Court of Charlemagne: A Case of Monstrous Regiment?, in: Nelson, Frankish World, 223-242.

Nelson, Janet L. and Theuws, Frans (eds.), Rituals of Power: From Late Antiquity to the Early Middle Ages (Leiden etc., 2000).

Nelson, Janet L. (ed.), Medieval Polities and Modern Mentalities (Cambridge, 2006)

Nelson, Janet L., Why Are There so Many Different Accounts of Charlemagne's Imperial Coronation?, in: Janet L. Nelson (ed.), Courts, Elites, and Gendered Power in the Early Middle Ages: Charlemagne and Others, VCSS 878 (Aldershot, 2007) 1-27.

Nithard, Historiae, ed. Georg H. Pertz, MGH SS rerum Germanicarum in usum scholarum [44] (Hanover 1839, repr. 1965).

Notker, Gesta Karoli, ed. Hans F. Haefele, MGH SS rerum Germanicarum nova series [12] (Hanover, 1959, reprinted 1980).

Paschasius Radbertus, Epitaphium Arsenii, ed. Ernst Dümmler, Abhandlungen der königlichen Akademie der Wissenschaften zu Berlin, Philosophische und historische Klasse 2 (Berlin, 1900).

Patzold, Steffen, Eine »loyale Palastrebellion« der »Reichseinheitspartei«? Zur »Divisio imperii« von 817 und zu den Ursachen des Aufstandes gegen Ludwig den Frommen im Jahre 830, Frühmittelalterliche Studien 40 (2006) 43-77.

Patzold, Steffen, Episcopus. Wissen über Bischöfe im Frankenreich des späten 8. bis frühen 10. Jahrhunderts (Sigmaringen, 2008).

Patzold, Steffen, Bischöfe als Träger der politischen Ordnung des Frankenreichs im 8./9. Jahrhundert, in: Pohl and Wieser, Der frühmittelalterliche Staat, 255-268.

Patzold, Steffen, Hraban, Gottschalk und der Traktat De oblatione puerorum, in: Philippe Depreux, Stéphane Lebecq, and Michel Perrin (eds.), Raban Maur et son temps, Collection Haut-Moyen Age 9 (Turnhout, 2010).

Patzold, Steffen, Einhards erste Leser: zu Kontext und Darstellungsabsicht der Vita Karoli, Viator Multilingual 42 (2011) 33-56.

Patzold, Steffen, "Einheit« versus "Fraktionierung«: Zur symbolischen und institutionellen Integration des Frankenreichs im 8./9. Jahrhundert, in: Walter Pohl, Clemens Gantner, and Richard Pain (eds.), Visions of Community in the Post-Roman World: The West, Byzantium and the Islamic World, 300-1100 (Farnham, 2012) 375-390.

Phelan, Owen, The Formation of Christian Europe. The Carolingians, Baptism, and the Imperium Christianum (Oxford, 2014).

Pohl, Walter (ed.), Kingdoms of the Empire. The Integration of Barbarians in Late Antiquity (Leiden, 1997).

Pohl, Walter, and Reimitz, Helmut (eds.), Strategies of Distinction. The Construction of Ethnic Communities, 300-80o (Leiden, 1998).

Pohl, Walter, Staat und Herrschaft im Frühmittelalter. Überlegungen zum Forschungsstand, in: Airlie et al., Staat im frühen Mittelalter, 9-38. 
Pohl, Walter, Ursprungserzählungen und Gegenbilder. Das archaische Frühmittelalter, in: Frank Rexroth (ed.), Meistererzählungen vom Mittelalter, Historische Zeitschrift, Beiheft 46 (München, 2007) 23-41.

Pohl, Walter, and Wieser, Veronika (eds.), Der frühmittelalterliche Staat: Europäische Perspektive. Forschungen zur Geschichte des Mittelalters 17 (Vienna, 2009).

Reimitz, Helmut, Grenzen und Grenzüberschreitungen im karolingischen Mitteleuropa, in: Walter Pohl and Helmut Reimitz (eds.), Grenze und Differenz im frühen Mittelalter, Österreichische Akademie der Wissenschaften, Philosophisch-historische Klasse, Denkschriften, 287; Forschungen zur Geschichte des Mittelalters (Vienna, 2000) 105-166.

Reuter, Timothy, Plunder and Tribute in the Carolingian Empire, Transactions of the Royal Historical Society 5/35 (1985) 75-94.

Reuter, Timothy, The End of Carolingian Military Expansion, in: Peter Godman and Roger Collins (eds.), Charlemagne's Heir: New Perspectives on the Reign of Louis the Pious (814-840) (Oxford, 1990) 391-405.

Rosenwein, Barbara H., Negotiating Space. Power, Restraint and Privileges of Immunity in Early Medieval Europe (Ithaca, 1998).

Sarti, Laury, Frankish Romanness and Charlemagne's Empire, Speculum 91/4 (2016) forthcoming.

Schieffer, Rudolf, Neues von der Kaiserkrönung Karls des Großen, Sitzungsberichte der Bayerische Akademie der Wissenschaften, phil.-hist. Klasse (Munich, 2004) 3-25.

Smith, Julia M. H., Europe after Rome: A New Cultural History, 500-10oo (Oxford, 2005).

Schneidmüller, Bernd, Von der deutschen Verfassungsgeschichte zur Geschichte politischen Ordnungen und Identitäten im europäischen Mittelalter, Zeitschrift für Geschichtswissenschaft 53 (2005) 485-500.

Schramm, Percy E., Kaiser, Könige, Päpste. Gesammelte Aufsätze zur Geschichte des Mittelalters, Band I (Stuttgart, 1968).

Thegan, Gesta Hludowici imperatoris, ed. Ernst Tremp, MGH SS rerum Germanicarum in usum scholarum seperatum editi [64] (Hanover, 1995).

Wenskus, Reinhard, Stammesbildung und Verfassung. Das Werden der frühmittelalterlichen gentes (Köln, 1961).

Wickham, Chris, Framing the Early Middle Ages (Oxford, 2005).

Wood, Ian and Sawyer, Peter (eds.), Early Medieval Kingship (Leeds, 1979).

Wood, Ian, Report: The European Science Foundation's Programme on the Transformation of the Roman World and the Emergence of the Early Middle Ages', Early Medieval Europe 6 (1997) 217-227.

Wood, Ian, John Michael Wallace-Hadrill, Proceedings of the British Academy 124 (2004) 333-355.

Wood, Ian, Entrusting Western Europe to the Church, 400-750, Transactions of the Royal Historical Society (Sixth Series) 23 (2013) 37-73.

Wood, Ian, The Modern Origins of the Early Middle Ages (Oxford, 2013).

Wood, Ian, The Transformation of Late Antiquity, 1971-2015, Networks and Neighbours, forthcoming.

Wormald, Patrick and Nelson, Janet L. (eds.), Lay Intellectuals in the Carolingian World (Cambridge, 2007). 